\title{
Reclassification of Pseudomonas mephitica Claydon and Hammer 1939 as a later heterotypic synonym of Janthinobacterium lividum (Eisenberg 1891) De Ley et al. 1978
}

\author{
Correspondence \\ Peter Kämpfer \\ peter.kaempfer@agrar.uni- \\ giessen.de
}

\author{
Peter Kämpfer, ${ }^{1}$ Enevold Falsen ${ }^{2}$ and Hans-Jürgen Busse ${ }^{3}$ \\ ${ }^{1}$ Institut für Angewandte Mikrobiologie, Justus-Liebig-Universität Giessen, D-35392 Giessen, \\ Germany \\ ${ }^{2}$ Culture Collection University Göteborg, Dept. of Clinical Bacteriology, S-41346 Göteborg, Sweden \\ ${ }^{3}$ Institut für Bakteriologie, Mykologie und Hygiene, Veterinärmedizinische Universität, A-1210 Wien, \\ Austria
}

\begin{abstract}
Pseudomonas mephitica CCUG $2513^{\top}$ has been reinvestigated to clarify its taxonomic position. 16S rRNA gene sequence comparisons demonstrated that this strain clusters phylogenetically closely with Janthinobacterium lividum ( $99.8 \%$ sequence similarity to the type strain). Investigation of fatty acid patterns, polar lipid profiles, polyamine patterns and quinone systems supported this delineation. Substrate utilization profiles and biochemical characteristics displayed no differences from the type strain of J. lividum, CCUG $2344^{\top}$. Therefore, the reclassification of Pseudomonas mephitica as a later heterotypic synonym of Janthinobacterium lividum is proposed, based upon the estimated phylogenetic position derived from 16S rRNA gene sequence data and chemotaxonomic and biochemical data.
\end{abstract}

Pseudomonas mephitica was initially proposed as the name for a bacterial strain isolated from butter (Claydon \& Hammer, 1939). The species description was based on morphological characteristics, i.e. a Gram-negative bacillus with polar flagellation, as well as physiological traits. The species name was included in the Approved Lists of Bacterial Names (Skerman et al., 1980).

Previously, it was recognized that $P$. mephitica is phylogenetically related to Janthinobacterium and related organisms (Anzai et al., 2000). The current definition of the genus Janthinobacterium is based on the descriptions of De Ley et al. (1978) and Sneath (1984) with the emendations of Lincoln et al. (1999) and Gillis \& Logan (2005). Most Janthinobacterium lividum strains produce violacein, but non-pigmented colonies are often encountered (Gillis \& Logan, 2005). P. mephitica did not produce pigmented colonies. Lincoln et al. (1999) pointed out that the fatty acid pattern serves to differentiate the genus Janthinobacterium from members of other genera showing a high degree (95\%) of $16 \mathrm{~S}$ rRNA gene sequence similarity. Q-8 is the major

Abbreviations: pNA, p-nitroanilide; pNP, p-nitrophenyl.

The GenBank/EMBL/DDBJ accession number for the 16S rRNA gene sequence of strain CCUG $2513^{\top}$ is AM748811.

A two-dimensional TLC of the polar lipids of P. mephitica CCUG $2513^{\top}$ is available as supplementary material with the online version of this paper. respiratory lipoquinone, as in all members of the Betaproteobacteria studied to date (Yokota et al., 1992). The major phospholipids are phosphatidylethanolamine, phosphatidylglycerol and diphosphatidylglycerol. The fatty acid composition comprises $\mathrm{C}_{10: 0} 3-\mathrm{OH}, \mathrm{C}_{12: 0}, \mathrm{C}_{12: 0} 2-\mathrm{OH}$, $\mathrm{C}_{14: 0}, \mathrm{C}_{16: 0}, \mathrm{C}_{16: 1} \omega 07 c, \mathrm{C}_{17: 0}$ cyclo and $\mathrm{C}_{18: 1} \omega 7 c$. The polyamine pattern, with the major compounds 2-hydroxyputrescine and putrescine, is in agreement with the characteristics of the Betaproteobacteria (Busse \& Auling, 1988).

In this study, P. mephitica CCUG $2513^{\mathrm{T}}$ was studied for its exact taxonomic position along with J. lividum CCUG $2344^{\mathrm{T}}$. The $16 \mathrm{~S}$ rRNA gene sequences (both $1388 \mathrm{bp}$ ) were studied as described by Kämpfer et al. (2003) and shared $99.8 \%$ similarity.

For polar lipid, quinone and polyamine analyses, cells were grown on PYE medium ( $0.3 \%$ peptone from casein, $0.3 \%$ yeast extract, $\mathrm{pH}$ 7.2). Analyses were carried out as described previously (Busse \& Auling, 1988; Tindall, 1990a, b; Altenburger et al., 1996; Stolz et al., 2007). The major phospholipids were detected to be phosphatidylethanolamine, phosphatidylglycerol and diphosphatidylglycerol. In addition, moderate amounts of an unknown aminolipid and an unknown phospholipid and minor to trace amounts of another unknown aminolipid and five unknown polar lipids were found (Supplementary Fig. S1, available in IJSEM Online). J. lividum CCUG $2344^{\mathrm{T}}$ exhibited the same profile (results not shown), and both 
profiles were in perfect agreement with those reported for the type strains of J. lividum and Janthinobacterium agaricidamnosum (Lincoln et al., 1999), although these authors did not detect minor components. The quinone system of $P$. mephitica CCUG $2513^{\mathrm{T}}$ consisted of $2 \%$ ubiquinone Q-7 and $98 \%$ Q-8 and the polyamine pattern also exhibited the characteristics of members of the Betaproteobacteria $\left[\mu \mathrm{mol}(\mathrm{g} \text { dry weight })^{-1}\right.$ : 2-hydroxyputrescine, 19.4; putrescine, 71.7; cadaverine, 0.3 ; spermidine, 1.0; spermine, 0.6].

Fatty acid methyl esters were prepared, separated and identified according to the instructions of the Microbial Identification System (MIDI, Microbial ID; Kämpfer \& Kroppenstedt, 1996). The fatty acid profiles of $P$. mephitica CCUG $2513^{\mathrm{T}}$ and J. lividum CCUG $2344^{\mathrm{T}}$ are shown in Table 1. No significant differences were found between the fatty acid profiles of the two strains.

All these chemotaxonomic traits clearly distinguish $P$. mephitica CCUG $2513^{\mathrm{T}}$ from members of the genus Pseudomonas sensu stricto, which show a quinone system containing ubiquinone Q-9 (Yokota et al., 1992) and a polyamine pattern with the predominant compounds putrescine and spermidine (Busse \& Auling, 1988), and are in excellent agreement with the characteristics of J. lividum.

Physiological/biochemical tests were performed with methods described previously (Kämpfer et al., 1991). Strains CCUG $2344^{\mathrm{T}}$ and CCUG $2513^{\mathrm{T}}$ shared the following biochemical characteristics. L-Alanine $p$-nitroanilide (pNA), bis- $p$-nitrophenyl (pNP) phosphate, bis-pNP phenylphosphonate, $\mathrm{pNP} \beta$-D-glucopyranoside and L-proline pNA are hydrolysed on the basis of the method described by Kämpfer et al. (1991). The following compounds are not hydrolysed: $\mathrm{pNP} \beta$-D-galactopyranoside, $\mathrm{pNP} \beta$-D-glucuronide, $\mathrm{pNP} \alpha$-D-glucopyranoside, pNP $\beta$-D-xylopyranoside, bis-pNP phosphorylcholine and $\gamma$-L-glutamate pNA. The following compounds are used as sole sources of carbon: $\mathrm{N}$-acetylgalactosamine, L-arabinose,

Table 1. Cellular fatty acid compositions (\%) of J. lividum CCUG $2344^{\top}$ and P. mephitica CCUG $2513^{\top}$

\begin{tabular}{|lcc|}
\hline Fatty acid & $\begin{array}{c}\text { J. lividum } \\
\text { CCUG } \text { 2344 }^{\text {T }}\end{array}$ & $\begin{array}{c}\text { P. mephitica } \\
\text { CCUG 2513 }^{\text {T }}\end{array}$ \\
\hline $\mathrm{C}_{10: 0}$ & 0.5 & 0.4 \\
$\mathrm{C}_{10: 0}$ 3-OH & 2.9 & 4.6 \\
$\mathrm{C}_{12: 0}$ & 4.3 & 3.6 \\
$\mathrm{C}_{12: 0} 2-\mathrm{OH}$ & 0.5 & 1.9 \\
$\mathrm{C}_{14: 0}$ & 0.7 & 1.0 \\
$\mathrm{C}_{16: 1} \omega 7 c^{\star}$ & 41.9 & 43.8 \\
$\mathrm{C}_{16: 0}$ & 39.0 & 33.1 \\
$\mathrm{C}_{17: 0}$ cyclo & 5.2 & 5.4 \\
$\mathrm{C}_{18: 1} \omega 7 c$ & 4.3 & 4.0 \\
iso- $_{19: 0}$ & 0.8 & 2.0 \\
\hline
\end{tabular}

${ }^{\star}$ Fatty acid $\mathrm{C}_{16: 1} \omega 7 \mathrm{c}$ is included in summed feature $3\left(\mathrm{C}_{16: 1} \omega 7 c\right.$ and/ or iso- $\left.\mathrm{C}_{15: 0} 2-\mathrm{OH}\right)$.
L-arbutin, D-fructose, D-galactose, D-glucose, maltose, Dribose, sucrose, D-xylose (weakly), D-mannitol (weakly), D-sorbitol (weakly), citrate, fumarate, glutarate, DL-3hydroxybutyrate, DL-lactate, L-malate, 2-oxoglutarate, pyruvate (weakly), L-alanine (weakly), L-proline (weakly) and L-serine (weakly). The following compounds are not utilized on the basis of the method described by Kämpfer et al. (1991): D-gluconate, acetate, propionate, cis- and trans-aconitate, 4-aminobutyrate, itaconate, mesaconate, $\beta$-alanine, L-aspartate, L-leucine, L-ornithine, L-serine, $\mathrm{N}$ acetylglucosamine, D-cellobiose, D-mannose, $\alpha$-D-melibiose, L-rhamnose, salicin, trehalose, adonitol, inositol, maltitol, putrescine, adipate, azelate, suberate, L-histidine, L-phenylalanine and L-tryptophan. Acids are produced from D-glucose, sucrose (weakly) and L-arabinose. No acids are produced from lactose, D-mannitol, dulcitol, salicin, adonitol, inositol, sorbitol, raffinose, rhamnose, maltose, D-xylose, trehalose, cellobiose, methyl D-glucoside, erythritol, melibiose, D-arabitol or D-mannose.

On the basis of these results, it is clear that P. mephitica CCUG $2513^{\mathrm{T}}$ is not a member of the genus Pseudomonas sensu stricto and, hence, we propose that the name Pseudomonas mephitica Claydon and Hammer 1939 is a later heterotypic synonym of Janthinobacterium lividum (Eisenberg 1891) De Ley et al. 1978 and that P. mephitica CCUG $2513^{\mathrm{T}}$ should be assigned to J. lividum based on: (i) $99.8 \% 16 \mathrm{~S}$ rRNA gene sequence similarity between $\mathrm{J}$. lividum CCUG $2344^{\mathrm{T}}\left(=\mathrm{DSM} 1522^{\mathrm{T}}\right)$ and P. mephitica CCUG $2513^{\mathrm{T}}$ (our confirmation: GenBank accession numbers Y08846 and AM748811, respectively), (ii) identical quinone systems, (iii) identical polar lipid profiles, (iv) highly similar polyamine patterns, (v) similar fatty acid profiles (Table 1) and (vi) identical biochemical test results.

\section{References}

Altenburger, P., Kämpfer, P., Makristathis, A., Lubitz, W. \& Busse, H.-J. (1996). Classification of bacteria isolated from a medieval wall painting. J Biotechnol 47, 39-52.

Anzai, Y., Kim, H., Park, J. Y., Wakabayashi, H. \& Oyaizu, H. (2000). Phylogenetic affiliation of the pseudomonads based on 16S rRNA sequence. Int J Syst Evol Microbiol 50, 1563-1589.

Busse, H.-J. \& Auling, G. (1988). Polyamine pattern as a chemotaxonomic marker within the Proteobacteria. Syst Appl Microbiol 11, 1-8.

Claydon, T. J. \& Hammer, B. W. (1939). A skunk-like odor of bacterial origin in butter. J Bacteriol 37, 251-258.

De Ley, J., Segers, P. \& Gillis, M. (1978). Intra and intergeneric similarities of Chromobacterium and Janthinobacterium ribosomal ribonucleic acid cistrons. Int J Syst Bacteriol 28, 154-168.

Eisenberg, J. (1891). Bacteriologische Diagnostik, Hilfstabellen zum Gebrauche beim Praktischen Arbeiten, 3rd edn. Hamburg: Leopold Voss (in German).

Gillis, M. \& Logan, N. (2005). Genus IV. Janthinobacterium De Ley, Segers and Gillis 1978, 164, ${ }^{\mathrm{AL}}$ emend. Lincoln, Fermor and Tindall 1999, 1586. In Bergey's Manual of Systematic Bacteriology, 2nd edn, vol. 2, part C, pp. 636-642. Edited by D. J. Brenner, N. R. Krieg, J. T. Staley \& G. M. Garrity. New York: Springer. 
Kämpfer, P. \& Kroppenstedt, R. M. (1996). Numerical analysis of fatty acid patterns of coryneform bacteria and related taxa. Can J Microbiol 42, 989-1005.

Kämpfer, P., Steiof, M. \& Dott, W. (1991). Microbiological characterization of a fuel-oil contaminated site including numerical identification of heterotrophic water and soil bacteria. Microb Ecol 21, 227-251.

Kämpfer, P., Dreyer, U., Neef, A., Dott, W. \& Busse, H.-J. (2003). Chryseobacterium defluvii sp. nov., isolated from wastewater. Int J Syst Evol Microbiol 53, 93-97.

Lincoln, S. P., Fermor, T. R. \& Tindall, B. J. (1999). Janthinobacterium agaricidamnosum sp. nov., a soft rot pathogen of Agaricus bisporus. Int J Syst Bacteriol 49, 1577-1589.

Skerman, V. B. D., McGowan, V. \& Sneath, P. H. A. (editors) (1980). Approved lists of bacterial names. Int J Syst Bacteriol 30, 225-420.
Sneath, P. H. A. (1984). Genus Janthinobacterium De Ley, Segers and Gillis 1978, 164 ${ }^{\mathrm{AL}}$. In Bergey's Manual of Systematic Bacteriology, vol. 1, pp. 376-377. Edited by N. R. Krieg \& J. G. Holt. Baltimore: Williams \& Wilkins.

Stolz, A., Busse, H.-J. \& Kämpfer, P. (2007). Pseudomonas knackmussii sp. nov. Int J Syst Evol Microbiol 57, 572-576.

Tindall, B. J. (1990a). A comparative study of the lipid composition of Halobacterium saccharovorum from various sources. Syst Appl Microbiol 13, 128-130.

Tindall, B. J. (1990b). Lipid composition of Halobacterium lacusprofundi. FEMS Microbiol Lett 66, 199-202.

Yokota, A., Akagawa-Matsushita, M., Hiraishi, A., Katayama, Y., Urakami, T. \& Yamasato, K. (1992). Distribution of quinone systems in microorganisms: Gram-negative eubacteria. Bull Jpn Fed Cult Coll 8, 136-171. 